Revista da Seção Judiciária do Rio de Janeiro

\title{
DE LOS IVEZES E DE LO QVE IVDGAN: A FUNÇÃO DOS JUÍZES NO FUERO JUZGO
}

\section{DE LOS IVEZES E DE LO QVE IVDGAN: THE ROLE OF THE JUDGES IN THE FUERO JUZGO}

Mayara Ramos Saldanha ${ }^{1}$

Resumo: Durante o reinado de Fernando III (1217-1252) em Leão e Castela uma versão do Liber Iudiciorum, antigo código jurídico visigodo, foi traduzida do latim para o vernáculo com o nome de Fuero Juzgo e concedida às regiões recém-conquistadas no movimento expansionista derivado do processo de Reconquista. Como parte de um projeto político de caráter centralista, o estabelecimento do Fuero Juzgo visava garantir maior ordenação para o reino castelhano-leonês, ao mesmo tempo em que reforçava o lugar do monarca enquanto responsável pela justiça, utilizando-se da tradição jurídica visigoda como fundamento. Um aspecto particular dessa fonte diz respeito às normas estabelecidas no Livro II, Título I, intitulado "De los ivezes e de lo qve ivdgan", cujas normas dispõem sobre a regulação da atividade dos juízes e o exercício de sua função. Nossa proposta no presente trabalho é analisar as normas inseridas no Título I com vias de compreender como o Fuero Juzgo configura a atuação dos juízes e suas respectivas atribuições. Para isso faremos uma breve exposição do contexto histórico do reinado de Fernando III, como forma de entender a necessidade de tradução e implementação da obra naquele momento, e em seguida analisaremos os dispositivos contidos no Livro II, Título I.

Palavras-chave: Juízes. Fuero Juzgo. Leão e Castela. Direito Medieval.

\begin{abstract}
During the reign of Fernando III (1217-1252) in Leon and Castille a version of the Liber Iudiciorum, the old Visigoth legal code, was translated from Latin to the vernacular under the name of Fuero Juzgo and given to the newly conquered regions under the Reconquest process. As part of a centralist political project, the establishment of the Fuero Juzgo aimed the organization of the Castilian-Leonese kingdom, while reinforcing the king's role as responsible for justice, using the Visigothic legal tradition as basis. A particular aspect of this code are the norms elaborated in Book II, Title I, entitled "De los ivezes and de lo qve ivdgan", that discuss the regulation of the activity of judges and their functions. The main goal of

\footnotetext{
${ }^{1}$ Mestranda em História pelo Programa de Pós-Graduação em História (PPHR) da Universidade Federal Rural do Rio de Janeiro (UFRRJ). Bolsista CAPES pelo PPHR, desenvolvendo a pesquisa intitulada "A organização do processo judicial como instrumento de afirmação da monarquia castelhana no século XIII: uma análise comparativa do Fuero Juzgo e do Fuero Real", sob a orientação do Professor Dr. Yllan de Mattos Oliveira.
} 
Revista da Seção Judiciária do Rio de Janeiro

this paper is to analyze the rules included in Title I and to understand how the Fuero Juzgo configures the judges' performance and their attributions. First, a brief exposition of the historical context is presented followed by an analysis of the laws in the Book II, as a way to comprehend the necessity of the code translation at that time.

Keywords: Judges. Fuero Juzgo. Leon and Castille. Medieval Law.

Recebido em: 30/09/2021 Aceito para publicação em: 01/12/2021 
Revista da Seção Judiciária do Rio de Janeiro

\section{INTRODUÇÃO}

A Península Ibérica no geral, e os reinos de Leão e Castela em particular, são herdeiros de uma rica tradição jurídica que recebeu inúmeras influências ao longo do tempo: romanas, germânicas, judaicas e muçulmanas são apenas algumas delas. Desde a conquista romana do território, o direito escrito passou a ser parte da realidade peninsular, utilizado para garantir a justiça aos povos, para ordenar a convivência interna e para legitimar governantes. O papel da Igreja Católica foi fundamental para o desenvolvimento e manutenção desse direito, em uma relação estreita com a monarquia.

A partir do século XI, com o movimento de retomada pelos cristãos dos territórios que estavam sob domínio muçulmano desde o século VIII, o direito adquiriu cada vez mais importância como instrumento de organização dos reinos que iam ganhando forma. Além disso, o elemento de tradição, que muitas vezes era buscado nas heranças do império romano e dos reinos visigodos, garantia aos novos monarcas autoridade para que exercessem seu papel enquanto tal, fazendo frente aos demais grupos em disputa.

A unificação dos reinos de Leão e Castela já era pretendida desde aquele momento e vivenciou fases de união e desintegração, até ser efetuada em definitivo no século XIII. Esse processo aliado às contínuas anexações territoriais oriundas da guerra com os muçulmanos gerou uma pluralidade jurídica que dificultava o controle régio das questões internas, pois cada região podia ser regida por um código jurídico próprio.

Assim, quando Fernando III (1217-1252) promoveu a unificação em 1230, era necessário não somente lidar com as questões desafiadoras decorrentes desse empreendimento, como a revolta de parte da nobreza contrária ao seu governo, mas também proceder a organização interna do reino recém-unificado e dos novos territórios que estavam sendo conquistados. Para isso, uma renovação ampla em 
Revista da Seção Judiciária do Rio de Janeiro

diversos aspectos era imprescindível, no âmbito econômico, militar e, principalmente, no jurídico.

O reinado de Fernando III, O Santo, foi marcado pelo domínio de um amplo território, porém muito heterogêneo, onde o avanço contra os muçulmanos se ampliou juntamente ao fortalecimento e enriquecimento da nobreza que fazia parte dessa empreitada. A unificação dos reinos de Leão e Castela contribuiu para que a tarefa legislativa fosse uma prioridade da monarquia, uma necessidade para se manter a unificação territorial.

Sua política nessa área em grande parte seguiu o caminho de seus antecessores, com a concessão e confirmação de códigos já existentes, os chamados fueros. Porém, o diferencial foi a tradução do Liber Iudiciorum, clássica legislação visigótica do século VII, como Fuero Juzgo, sendo parte de um projeto de centralidade jurídica que apenas começava a ganhar força e que teria maior amplitude no reino de seu filho e sucessor Afonso X.

Alguns aspectos importantes sobre a obra são desconhecidos, como sua data de composição ou promulgação, já que existiram diversas traduções do texto visigótico do latim para o romance. No entanto, parte da historiografia especializada admite a data provável de 1241 para sua distribuição às municipalidades, com base no compromisso firmado pelo monarca no prólogo da Carta de Fuero, outorgada à Córdoba no mesmo ano, onde ele determina que os juízos se deem conforme o Fuero Juzgo. ${ }^{2}$

\footnotetext{
${ }^{2}$ Maiores informações sobre o debate acerca da datação do Fuero Juzgo podem ser encontradas em: JIMÉNEZ, M. G. Fernando III El Santo, Legislador. Boletín de la Real academia Sevillana de Buenas Letras: Minervae Baeticae, n. 29, p. 111 - 131, 2001. LLUCH, M. C. Las fechas del Fuero Juzgo: avatares históricos e historiigráficos de la versión romance de la ley visigótica (II). In: JIMÉNEZ, A. N.; SERENA, A. L. (coords.) El español através del tiempo. Estudios de lingüística histórica ofrecidos a Rafael Cano Aguilar, Sevilla, Editorial de la Universidad de Sevilla, 2016, p.47-68. A Carta de Fuero pode ser encontrada em: Fernando III, Rey de España. La carta de Fuero concedida a la Ciudad de Córdoba por el rey D. Fernando III / copiada del original, traducida al castellano y anotada por Victoriano Rivera Romero. -- Córdoba: [s.n.], 1881 (Imp., lib. y litog. del Diario), VI, 68 p., $[1]$ h. de lámina; $20 \quad \mathrm{~cm}$. Disponível em: https://biblioteca.cordoba.es/index.php/biblio-digital/libros-folletos/563-obras-varias-xix/222-1881-la-c arta-de-fuero-concedida-a-la-ciudad-de-cordoba-victoriano-rivera-romero.html. Acesso em: 08 ago. 2021.
} 
Revista da Seção Judiciária do Rio de Janeiro

A versão aqui utilizada é derivada do manuscrito de Murcia, datado de 1288, que foi editada pela Real Academia Espanhola em 1815 e cotejada com outros devido à sua deterioração. Embora seja um manuscrito posterior ao reinado de Fernando III, sua escolha se justifica por ser o mais reconhecido e aceito pelos pesquisadores do tema.

O Fuero Juzgo é composto por um total de doze livros que tratam de assuntos tão diversificados quanto o ato de legislar, a função dos juízes, questões ligadas ao casamento, linhagens e heranças, relações de compra e venda, questões criminais, entre outras. $\mathrm{O}$ ponto que interessa ao propósito deste trabalho está presente no Livro II, "De los juicios y causas", Título I, intitulado "De los ivezes e de lo qve ivdgan", cujas normas dispõem sobre a regulação da atividade dos juízes e o exercício de sua função.

No Título I encontram-se 31 dispositivos legais que dispõem sobre o recebimento das leis pelo príncipe e pelo povo, bem como da atuação dos juízes no exercício de sua função. Esse era um importante tópico, tendo em vista a pretensão de Fernando de organizar as relações internas do reino, e se refletia na escolha dos juízes e na designação de suas tarefas, por exemplo. O Fuero Juzgo era uma tentativa de ordenar e controlar esse processo, que até então variava em cada região de acordo com cada fuero local em vigor.

Nesse sentido, nossa proposta é analisar essas normas, com vias de compreender como o Fuero Juzgo configura a atuação dos juízes e suas respectivas atribuições. Para isso faremos uma breve exposição da tradição jurídica castelhano-leonesa e do contexto histórico do reinado de Fernando III, como forma de entender a necessidade de tradução e implementação da obra naquele momento, passando em seguida à análise dos dispositivos contidos no Título I do Livro II. 
Revista da Seção Judiciária do Rio de Janeiro

\section{A HERANÇA JURÍDICA PENINSULAR}

O Império Romano dominou a região da Península Ibérica ainda no século II, sendo nomeada inicialmente como Hispania, recebeu identidade política e converteu-se em Diocesis Hispaniarum no século seguinte por ordem do imperador Diocleciano (RUCQUOI, 1995, p. 21). A partir desse momento ela ficou submetida à legislação romana, tornando-se herdeira do direito que lá se estabeleceu.

No início do século $V$, uma série de invasões de povos Vândalos, Suevos, Alanos e depois Visigodos, iniciou uma nova fase na região que colocou fim à exclusividade do domínio romano (RUCQUOI, 1995, p. 24). Apesar disso, muitos de seus costumes, mentalidade e forma de organização foram absorvidas por esses povos e ressignificados, ou seja, não houve exatamente uma ruptura e sim uma transformação.

Até então, muito do sistema jurídico utilizado era de origem romana, tanto nos acordos como nas leis. As terras eram concedidas através de um foedus ${ }^{3}$ e os diferentes povos disputavam os territórios junto ao Império, travando alianças ou guerras entre si. Mesmo com a queda do Império Romano do Ocidente (476 d.C.) e o estabelecimento dos povos germânicos nessa região, as heranças romanas permaneceram. A instalação dos Visigodos merece destaque devido à criação do seu reino, que buscou se constituir a partir de referências políticas e administrativas romanas, como forma de garantir sua legitimação.

O Código de Eurico, como a sua revisão promulgada em 506, o Breviarium Alaricum, códigos territoriais largamente devidos aos legistas romanos que rodeavam o rei, inscreviam-se na tradição dos códigos romanos e, em especial, na do Código de Teodósio de 438. Além disso, o campo em que os Visigodos exerciam futuramente a sua autoridade correspondia, em grande

\footnotetext{
${ }^{3} \mathrm{O}$ foedus era um acordo onde os romanos permitiam que outros povos vivessem em seu território em troca de fornecer homens para o exército, pagar um imposto e defender as fronteiras imperiais. Cf. GUERRAS, M. S. Os povos bárbaros. São Paulo: Editora Ática, 1987.p.39-40.
} 
Revista da Seção Judiciária do Rio de Janeiro

parte, à circunscrição territorial nascida das reformas de Diocleciano (...). (RUCQUOI, 1995, p. 32-33).

A chegada ao trono de Leovigildo em 569 marcou a consolidação dos Visigodos na região. Ele instituiu um programa político que visava unificar o território, fixar a capital em Toledo, cunhar moedas, adotar símbolos imperiais, como coroa e cetro, e procedeu a redação de um código de leis que pode ter sido uma adaptação do Breviário de Alarico ou Lex Romana Visigothorum.

Após a sua morte, seu filho Recaredo assumiu o trono em 587 e se converteu ao catolicismo, firmando uma aliança com a Igreja, indispensável para a plena unificação do reino. Esse acordo concedeu à Igreja o poder de legitimar e sacralizar os reis, que através disso poderiam assumir o poder sem estarem ligados a uma estrutura dinástica. Foi a partir de então que "(...) a Igreja forneceu ao poder visigótico as suas bases intelectuais e jurídicas herdadas de Roma e de Constantinopla e largamente inspiradas nos modelos bíblicos." (RUCQUOI, 1995, p. 42).

Desde cedo já se mostravam as intrincadas relações entre o poder eclesiástico e o poder temporal na Península Ibérica, que perdurou por muito tempo. No IV Concílio de Toledo, em 633, presidido por Isidoro de Sevilha, foi oficializado o acordo onde a Igreja ratificava o poder dos reis através da unção em troca da ação deles como cristãos atuantes e disciplinados. O VIII Concílio de Toledo, em 653, convocado pelo rei Recesvinto, previa que dentre as funções do monarca estavam a defesa e a proteção da fé católica, fato que influenciou as guerras contra os muçulmanos, que foram intensificadas a partir do século XI. Além disso, o rei tinha a responsabilidade de agir bem e com justiça, o que serviu de justificativa para a reformulação feita nos códigos legislativos anteriores. Em 654, foi promulgado o Liber Iudicum ou Liber Iudiciorum, passando a ser aplicado a todos os habitantes da localidade (RUCQUOI, 1995, p. 43).

Dessa associação entre Igreja e monarquia adveio também a ideia da organização social como um desejo de Deus e o rei como figura escolhida para ser o 
Revista da Seção Judiciária do Rio de Janeiro

protetor, o guia, a "cabeça" do reino. A função jurídica era, portanto, um desses papéis a ser cumprido pelo monarca, que devia fazer as leis, organizar a justiça e manter a paz, contando sempre com o auxílio dos bispos.

A chegada dos muçulmanos à Península no século VIII trouxe inúmeras mudanças, e a convivência entre estes e os cristãos foi permeada de altos e baixos, acordos e disputas. No âmbito jurídico em muitos locais se conservou os sistemas romano e visigótico convivendo com o direito árabe. Os muçulmanos "(...) se contentavam com o império e com o poder de vida e de morte, deixando em vigor o direito e as instituições que encontraram; pelas leis árabes eram decididas as controvérsias entre eles, ou entre um árabe e um cristão." (LEME, 1958, p. 76-77).

Por ser o direito muçulmano uma das faces da religião, ele não era aplicado aos não muçulmanos, devendo estes pagar impostos em sinal de submissão, ter seu direito à propriedade de terras restringido e em casos de processos criminais o testemunho ou pena (se fosse entre um árabe e um cristão) eram diferenciados. 0 rito malekita ${ }^{4}$, desenvolvido pelo jurista Malik Ibn Anas, foi aplicado na Península Ibérica e era considerado o sistema jurídico mais próximo da tradição do profeta Maomé (GILISSEN, 1995, p. 122).

Como reação ao avanço muçulmano em grande parte do território, os francos conquistaram o nordeste da Península, onde conseguiram impedir que o avanço árabe continuasse. Nesse momento, já havia certa divisão entre o norte, de domínio cristão, e o sul, de domínio muçulmano, apesar de muitos cristãos ainda viverem no sul, onde alternavam-se fases de convivência pacífica ou violenta.

\footnotetext{
${ }^{4} \mathrm{O}$ rito malekita é parte de um sistema jurídico aplicado no mundo muçulmano, onde se destacaram quatro escolas principais: malekita, hanifita, chafeíta e hanbalite. Este rito se desenvolveu principalmente nas regiões do Marrocos, Tunísia e Argélia, além da Península Ibérica durante a conquista moura, sendo a doutrina oficial em Al-Andalus. Entre suas concepções mais importantes estão a defesa do Corão e da Sunna como fontes centrais para o direito. Para mais informações Cf. GILISSEN, J. O Direito Muçulmano. In: Introdução histórica ao Direito. Tradução de A. M. Hespanha. Lisboa: Fundação Calouste Gulbenkian, 1995. E ainda: QUESADA, J. M. O direito islâmico medieval (Fiqh). In: PEREIRA, R. H. S. (org.). 0 Islã clássico: itinerários de uma cultura. Editora Perspectiva, São Paulo: 2007. p. 213-246.
} 
Revista da Seção Judiciária do Rio de Janeiro

A reorganização dos reinos cristãos do norte, a partir do século IX, levou a construção de uma ideia de "unidade" ibérica pelos soberanos e clérigos, onde a herança dos visigodos e dos romanos era ressaltada e tentava-se instituir uma continuidade histórico-cultural. Essa era uma maneira de legitimar tanto as pretensões régias de novas conquistas territoriais e reforço de poder, quanto os ideais da Igreja de expansão da fé cristã e manutenção de seu prestígio e influência. No século XIII, essa ideia já estava profundamente consolidada na mentalidade dos cristãos daquela região ${ }^{5}$.

(...) os reis de Leão e, depois, os de Leão e Castela, podiam vangloriar-se de uma rica tradição literária e historiográfica que, desde o século IX, fundava o seu poder sobre uma legitimidade - a linhagem dos reis visigodos - e uma missão - a de restaurar a Espanha que os seus antepassados governavam. A salvaguarda de uma tradição e a manutenção dos textos de leis civis e religiosas "visigóticas" contribuíram para aumentar as reivindicações dos que governavam Leão (...) (RUCQUOI, 1995, p. 172).

Desse modo, teve início o processo de expansão e fortalecimento dos reinos cristãos através das guerras contra os muçulmanos, que dominavam o sul da península. Com a chegada de Fernando I ao trono em 1037, houve um momento de prosperidade econômica e demográfica que permitiu a expansão territorial e a primeira unificação dos reinos de Leão e Castela.

O fortalecimento das monarquias, a partir do século XII, permitiu que os reis exercessem o papel de autoridade pública sobre os conflitos, o que antes era monopólio papal, e assim afirmassem seu poder no âmbito da guerra e do Direito.

Las aportaciones jurídicas y doctrinales de los juristas formados al calor Del
derecho romano vinieron a reforzar La posición política y jerárquica de estos
reyes al menos en dos direcciones: de um lado, hacia el interior, La
obediencia al monarca de los nacidos em el reino - los naturales - se
superpuso progresivamente al criterio de fidelidade feudal o personal que
um señor podía exigir a su vasallo, com lo que se consolida su superioridad
como autoridade pública frente a cualquier otra instancia de poder. Em el
terreno militar, esta tendência suponía dejaren manos de los monarcas el
monopolio de La violência en sus propios reinos, quedándose sin
competidores de ningún tipo. De outro lado, frente al exterior, se acabo

\footnotetext{
${ }^{5}$ Para mais informações Cf. NOGUEIRA, C. R. A reconquista Ibérica: a construção de uma ideologia. História Instituições Documentos, Sevilla, n. 28, p. 277-295, 2001.
} 
Revista da Seção Judiciária do Rio de Janeiro

aceptando el principio de que el rey era emperador em su reino, de manera que por encima de él no quedaban ingún superior juridisccional al que recurrir para dirimir um conflicto. (FITZ, 2003, p. 43-44)

Foi nesse contexto que se desenvolveram, ainda no século IX, os forais ou fueros, que eram

(...) a princípio cartas pelas quais eram concedidas terras para povoamento, tendo os contemplados direitos mais ou menos extensos e obrigando-se a certos tributos ou serviços; outros eram verdadeiras leis civis ou criminais, econômicas e administrativas, concedidas a um conselho existente ou que se constituíra, em que faltavam costumes ou leis consuetudinárias, ou em que elas devessem ser reformadas; (LEME, 1958, p. 7).

Quando o Liber Iudicum herdado dos visigodos caiu em desuso, os territórios cristãos passaram a utilizar-se do costume e dos formulários notariais para regular as questões jurídicas. Com a expansão territorial os reis começaram a conceder "cartas de población" para as regiões recém-conquistadas, o que concedia aos seus habitantes privilégios e uma forma de resolver as questões judiciais, consolidado nas chamadas fazañas. $\mathrm{O}$ ordenamento jurídico, portanto, era a prática do que estava contido no fuero, ainda que fosse comum que as normas do costume fossem tomadas como normas jurídicas, sendo conhecidas como "fuero por fazaña".

A partir do século XI os reis passaram a ditar novas disposições aos concelhos das vilas que mediante acordos estabelecem normas jurídicas complementares ao fuero. A nobreza, que estava envolvida nas guerras contra os muçulmanos, fornecendo homens, financiamento e provisões para os reis, ficavam responsáveis pelo repovoamento e administração das cidades e vilas, passando a atuar como senhores daquele local. Eram-Ihes concedidos fueros, que Ihes garantiam o poder de justiça, o que acabou originando uma pluralidade de legislações.

Assim, esses diversos fueros que passaram a regular a sociedade eram diferenciados entre si e atendiam aos interesses da nobreza local, garantindo-Ihes seus privilégios e também reforçando as práticas que já faziam parte do costume do povo e da região. Com o tempo, iam sendo adicionadas novas disposições de origem régia que confirmavam a sua validade e autoridade. 
Revista da Seção Judiciária do Rio de Janeiro

\begin{abstract}
El casuísmo inherente a toda decisión judicial, base del fuero, y el carácter de privilegio que entrañaban las cartas de población acentuaron aún más el particularismo del ordenamiento jurídico. No hubo um fuero general a todo el reino, sino fueros locales que cada ciudad o villa cuido celosamente de salvaguardar, solicitando del rey o señor la concesión de uma carta de fuero, que junto a nuevos privilegios o exenciones confirmara las normas más características o apreciadas de su próprio ordenamiento. (GARCÍA-GALLO DE DIEGO, 1984, p. 134).
\end{abstract}

No século XII, o ordenamento foral já ganhara grande desenvolvimento e popularidade, principalmente devido a retomada dos territórios e seu repovoamento, já que esses códigos atuavam demarcando certa autonomia e reconhecimento jurídico à localidade. Nos fueros poderia haver tanto elementos reconhecidos pelo direito do costume da comunidade quanto novas disposições feitas pela autoridade que o concedia, a saber, o senhor, laico ou eclesiástico, ou o rei (GILISSEN, 1995, p. 266).

Inicialmente, ainda entre os séculos IX e XI, os forais eram chamados fueros breves ou cartas pueblas e continham um pequeno conjunto de preceitos, normalmente não mais do que vinte, que concediam privilégios urbanos ou rurais a determinada localidade, colocavam por escrito o direito do costume e regulavam situações específicas. No entanto, a partir do século XII esses fueros vão sendo ampliados, passando a conter leis mais estruturadas e organizadas que regulamentavam o direito privado (questões relativas à herança, casamento e filhos), as relações entre servos, senhores e o rei, penalidades e a organização do processo jurídico.

Eram, portanto, "verdadeiros códigos jurídicos" chamados de fueros extensos. Aqui, além do conteúdo derivado do direito consuetudinário, incluíam-se também disposições que

(...) provém de julgamentos ou de decisões do conselho municipal, ou ainda foram copiadas de outros fueros; finalmente, sob a influência do direito romano que renasce, são aí inseridas disposições de origem romana. Os textos assim adaptados são submetidos à provação real ou, quando é o caso disso, senhorial. (GILISSEN, 1995, p. 267). 
Revista da Seção Judiciária do Rio de Janeiro

Esse é o caso do Fuero Juzgo, adotado pelo rei Fernando III durante seu reinado, na primeira metade do século XIII.

\begin{abstract}
No campo jurídico, Fernando III investiu na elaboração de um projeto de unificação jurídica que demolisse o particularismo de ordenamentos que caracterizava o reino castelhano em decorrência da política anterior de concessão foral. [...] O monarca mandou, então, traduzir para o romance 0 Liber Iudicum a que deu o nome de F] [Fuero Juzgo]. Texto que tinha a seu favor 0 alto valor simbólico que possuía por ser considerada a fonte primordial do direito visigodo. Era garantida a este texto, portanto, a tradição e a antiguidade necessária para estabelecer-se como base o direito da corte fernandina. O FJ possuía duas características primordiais: a heterogeneidade temática e a defesa clara do poder centralista monárquico. (SILVEIRA, 2016, p. 7).
\end{abstract}

Esse código foi redigido tomando por base o Liber Iudiciorum e era parte de um projeto que visava, entre outros objetivos, garantir a unidade e organização do reino. Para isso, Fernando III investiu na retomada de um código que trazia consigo uma alta carga de tradição romano-visigoda, o que reforçava seu poder enquanto responsável pela justiça e pelo direito.

\title{
3 O REINADO DE FERNANDO III
}

A ascensão de Fernando III ao trono castelhano foi um processo conturbado, com a morte de seu avô Afonso VIII em 1214, o sucessor tornou-se o primogênito Enrique, mas este veio a falecer precocemente três anos depois, tornando sua irmã Berenguela, mãe de Fernando, a herdeira.

O conde Álvaro Nuñez de Lara, pertencente à alta linhagem da nobreza castelhana, era então tutor de Enrique e regente, já que o infante contava com pouca idade na época. Com a morte do herdeiro, e a reivindicação de Berenguela de seu direito de sucessão, aumentou uma ferrenha disputa que já existia entre a nobreza, alimentada pelas críticas acerca do demasiado poder possuído pela família Lara. 
Revista da Seção Judiciária do Rio de Janeiro

Berenguela reuniu-se com parte desses ricos hombres que a apoiavam e decidiram buscar seu filho Fernando, que até este momento encontrava-se na corte de seu pai Afonso IX de Leão, para que pudessem ser proclamados juntos, com a intenção de renunciar em favor dele. Álvaro de Lara, de posse dessa informação, rumou para a corte de Afonso IX, de quem também era mayordomo $0^{6}$ para buscar apoio, apoiando-se nas pretensões que aquele também tinha sobre a coroa castelhana.

Conseguindo trazer Fernando, Berenguela e seus apoiadores partiram numa expedição por todo o reino arregimentando suporte para sua causa e reconhecimento de seu direito sucessório. Na Assembleia de Valladolid, onde estavam presentes os ricos hombes, bispos das principais dioceses e representantes dos concelhos, Berenguela foi reconhecida e cedeu em nome de Fernando, mas com a condição de que continuaria sendo consultada para decisões de governo. Fernando prometeu respeitar os fueros dos concelhos e manter inalterada as propriedades da nobreza por um prazo determinado.

Álvaro de Lara havia convencido Afonso IX a invadir Castela, mas o rei de Leão, vendo que isso não ocorria a contento, retornou para sua corte. Fernando, então já rei de Castela, investe contra Lara fazendo-o cativo e obrigando-o a se retirar para o reino de Leão. A paz entre Fernando e seu pai finalmente se deu no ano de 1218 ,

(...) conhecendo o poder do exército castelhano, Alfonso IX cedeu, mediante a explicação de que fazia guerra com Castela devido a uma dívida de dez mil maravedís que o rei Enrique I tinha com o reino de Leão, pela cessão do território de Santibáñez de la Mota. Em sua resposta o monarca argumentou que, se Fernando III lhe pagasse, não haveria mais guerra alguma. 0 monarca castelhano atendeu às reivindicações de seu pai, e em agosto de 1218 firmou, em Toro, um acordo que pôs fim às hostilidades entre Castela e Leão. (REIS, 2007, p. 34).

\footnotetext{
${ }^{6} \mathrm{O}$ mayordomo era um empregado da casa real que cuidava das questões econômicas e recursos fiscais.
} 
Revista da Seção Judiciária do Rio de Janeiro

Assim, iniciou-se o reinado de Fernando III sobre Castela, mas as coisas voltaram a ficar turbulentas com relação ao direito deste ao trono leonês, por parte de seu pai. Apesar de Fernando ter sido reconhecido como herdeiro do trono de Leão junto aos nobres e bispos do reino pelo Tratado de Cabreros de 1209, o próprio Afonso IX resolveu alterar esse ponto após a chegada do filho ao trono castelhano.

Através de mudanças no tratado, Afonso IX estabeleceu o reconhecimento de suas filhas Sancha e Dulce como herdeiras, no lugar de Fernando. Com a sua morte em 1230 as infantas até tentaram conseguir apoio para esta causa, dividindo parte da nobreza, mas seu número de apoiadores era significativamente baixo. Ainda assim, Berenguela percebeu que disso poderia advir uma nova disputa e orientou Fernando a entrar em acordo com suas irmãs. 0 trato firmado em 11 de dezembro de 1230 , estabeleceu uma renda vitalícia para as infantas em troca da renúncia delas à coroa.

Assim, em 1230 os reinos de Leão e Castela foram definitivamente unificados por Fernando III, que reinou até a sua morte em 1252, sendo sucedido por seu primogênito Afonso $X$. Alguns pontos aos quais o monarca deu especial atenção durante seu governo foram a continuidade do movimento expansionista e a ordenação do reino por meio da justiça, visando dirimir as inúmeras disputas entre os grupos nobiliárquicos e assegurar o controle dos novos territórios que eram incorporados.

A ampliação do território conquistado durante o reinado do monarca «Santo» tornou necessária uma política de organização dos novos territórios agora dominados que foi levada a cabo através de repartimientos entre os que haviam colaborado em sua conquista e que materializou 0 repovoamento de todos esses territórios al sul do rio Tajo. Com Fernando III chegou-se ao cume do processo expansionista dos reinos de Leão e Castela. (ANTÓN, 2014, p. 166) ${ }^{7}$.

\footnotetext{
${ }^{7}$ Do original: La ampliación del territorio conquistado durante el reinado del monarca «Santo» hizo necessaria una política de organización de los nuevos territorios ahora dominados que se llevó a cabo a través de repartimientos entre los que habían colaborado em su conquista y que vino a materializar la repoblación de todos estos territorios al sur del río Tajo. Con Fernando III se llegó al culmen del proceso expansivo de los reinos de León y Castilla. (ANTÓN, 2014, p. 166).
} 
Revista da Seção Judiciária do Rio de Janeiro

Acerca das conquistas, Fernando III retomou as campanhas militares em 1224, dominando as regiões de Córdoba em 1236, Murcia em 1243 e Jaén em 1246. Sobre Córdoba, capital andaluza e antiga capital do califado almóada, que estava em mãos muçulmanos desde a queda dos visigodos, sua tomada foi significativa, pois representava o poder da monarquia cristã frente ao inimigo muçulmano, o que reforçava a legitimidade do rei.

O reino havia atingido certa estabilidade política e econômica que contribuíram para essa política expansionista, a partir da retomada de novas regiões, Fernando foi thes concedendo fueros e dotando-as de uma legislação. Inicialmente esses fueros tinham fundamentos parecidos, dando origem às chamadas "família de fueros", embora ainda contassem com especificidades locais.

Após a retomada de Andaluzia e Murcia sentiu-se a necessidade de aplicar nesses territórios uma legislação única, que facilitasse seu controle e organização, com isso a concessão do Fuero Juzgo foi a saída encontrada por Fernando.

\begin{abstract}
A escolha do Fuero Juzgo para ser difundido para toda a Andaluzia e o reino de Murcia deveu-se, primeiramente, a fatores de ordem prática: sua melhor adequação às cidades de tradição moçárabe; o êxito da concessão desse código como Fuero de Toledo às zonas circunvizinhas conquistadas por Fernando III; sua característica de código amplo e completo. Há que se acrescentar uma razão de ordem ideológica: seu caráter de código oriundo da atividade legislativa dos reis visigodos; portanto, mais propício ao resgate da unidade pretendida por Fernando III e ao fortalecimento do poder real almejado pelo monarca. (REIS, 2007, p. 166).
\end{abstract}

Tratava-se da tradução do latim para o castelhano do antigo Código dos Visigodos ou Liber Iudiciorum, escrito ainda no século VII tomando por base o direito romano e o germânico. Conforme já ressaltado, admite-se a data de promulgação e início das concessões da obra no ano de 1241.

Entre as razões para a escolha desse fuero, uma que vale ser destacada é o uso de elementos ligados à religiosidade como justificativa do poder real, atribuindo a ele a responsabilidade pela manutenção da justiça e da verdade. O monarca 
Revista da Seção Judiciária do Rio de Janeiro

deveria não somente zelar pelo bem de seus súditos, mas tinha também o dever de proteger a Igreja e incentivar a vida espiritual.

A lei II do Título referente aos "De los ivezes e de lo qve ivdgan" trata justamente da submissão que todos, inclusive os reis, devem ter perante a justiça. $\mathrm{E}$ como as leis são instrumentos por meio dos quais a justiça é feita, é dever do rei garantir que elas sejam conhecidas e cumpridas (FJ, II, I, II) .

No século XIII a cúria régia já era composta também por legistas, especialistas no direito romano e canônico, que auxiliavam o monarca, além de haver maior presença de funcionários dedicados à administração do reino. Com Fernando III e Afonso X, aparecem ainda as cortes como organismo legislativo, para apreciar petições e representar a população a partir de 1250 .

A dominação territorial também tinha importância nesse contexto na medida em que demonstrava o poder régio. Em um momento onde os territórios estavam sendo retomados dos muçulmanos e os reis buscavam a unificação, o Fuero Juzgo objetivava garantir a autoridade sobre terras e homens através da legislação (BEJDER, 2008, p.7). O trabalho que iniciou-se com Fernando III foi ampliado no reinado de seu filho Afonso $X$, que deu continuidade às políticas de seu pai, visando garantir sua autoridade tanto interna quanto externamente.

Os reis castelhanos, Fernando III e, especialmente, Alfonso $\mathrm{X}$, buscaram paulatinamente afirmar essa preponderância interna e externamente, iniciando de forma mais sistemática um programa de centralização, onde o monopólio da justiça e sua consequente territorialização eram pontos basilares. (VEREZA, 2013, p. 56)

A pluralidade de fueros dificultava um maior controle régio sobre a forma como a justiça era aplicada no reino, ou mesmo sobre quem desempenhava as funções judiciais. Como eles variavam de acordo com os costumes locais, os grupos nobiliárquicos e mesmo urbanos, tinham mais abertura para determinar dispositivos ou indicar indivíduos que Ihes favorecessem. O Fuero Juzgo foi, portanto, um passo

\footnotetext{
${ }^{8}$ A partir daqui, como forma de facilitar a leitura do texto, adotaremos a seguinte notação para fazer referências às leis do Fuero Juzgo, após suas respectivas citações: (FJ, Livro, Título, Lei).
} 
Revista da Seção Judiciária do Rio de Janeiro

inicial na unificação jurídica que a monarquia pretendia para Leão e Castela, buscando aumentar sua esfera de influência e sua autoridade.

\section{DE LOS IVEZES E DE LO QVE IVDGAN}

A partir dos séculos XI e XII o direito passou por uma renovação no ocidente medieval, os códigos romanos clássicos foram retomados, o direito canônico se desenvolveu, as escolas de direito se proliferaram e constituíram um currículo básico para a formação dos juristas. Estes, depois de se especializarem, iam exercer seu ofício nos tribunais eclesiásticos e régios. Desse movimento resultaram ainda inúmeros códigos legislativos régios, incentivados por essa renovação.

A tradução e o estabelecimento do Fuero Juzgo no reino castelhano-leonês está, em certa medida, inserido nesse processo. Seu caráter unificador vai ao encontro da sistematização do direito que vinha ocorrendo, seja nos ambientes universitários onde se desenvolvia uma ciência jurídica, seja na Igreja que organizava seus procedimentos através da ordenação do direito canônico.

Schioppa (2014, p.132) argumenta que "a partir do século XIII, manifestaram-se na Península Ibérica tendências convergentes em vista da superação do particularismo" e exemplifica com a produção de fueros de caráter unificador como, entre outros exemplos, é o caso do Fuero Juzgo.

O Fuero Juzgo está dividido em doze livros, seguindo o Liber Iudiciorum, que também está assim dividido, com base no Código de Justiniano, texto clássico do direito romano. Vale destacar que a versão aqui utilizada é baseada no códice murciano do Fuero Juzgo, que resulta de uma compilação de leis visigodas desenvolvidas por vários monarcas visigodos, Chindasvinto, Recesvinto, Ervígio, com partes do Código de Eurico e do Breviário de Alarico (FJ, p. XXVI).

O objeto de análise deste trabalho é apenas o Livro II, Título I, que trata majoritariamente dos juízes e suas funções, mas também reforça a necessidade das 
Revista da Seção Judiciária do Rio de Janeiro

leis ali dispostas. O Título chamado "De los ivezes e de lo qve ivdgan" conta com 31 normas, que em resumo vão estabelecer as diretrizes para o trabalho dos juízes, mas também reforçar a importância das leis e do próprio Fuero Juzgo. "O livro segundo trata da organização judicial e da ordem processual, com suas matérias distribuídas em cinco títulos: juízes, atos do processo, procuradores e advogados, testemunhos, valor dos acordos orais e escritos." ${ }^{9}(\mathrm{FJ}, \mathrm{p}$. XXVIII).

Na Lei I é justificada a razão da existência do Fuero Juzgo, que é esclarecer e suplementar outras leis que não atendam a todas as necessidades da população. Levando em consideração o propósito sistematizador da obra, faz todo o sentido uma lei que se pretenda ordenadora do que até então estava confuso devido à pluralidade, ou mesmo complementar às leis locais naquilo onde elas deixavam um vácuo.

Já as Leis II e III vão se dedicar a dispor sobre a obediência às leis do Fuero Juzgo, que é dever de todos, inclusive dos reis, bem como a obrigação de conhecê-las. A lei II estabelece que

Onde se alguém quer obedecer a Deus, deve amar a justiça, e se a amar,
deve fazê-la todavia, e então o homem ama a justiça mais verdadeiramente
e mais firmemente quando tem um direito. E por isso nós que queremos
guardar os mandados de Deus, damos leis juntamente para nós e para
nossos submetidos, a que obedeçamos nós e todos os reis posteriores, e
todo o povo que é do nosso reino em geral. (FJ, II, I, II) ${ }^{10}$

De acordo com a concepção medieval, promover a justiça era um dever do rei já que, assim como Deus era a cabeça do corpo celeste e zelava pela paz e pelo ordenamento no céu, o monarca, seu representante na terra, era a cabeça do corpo social e responsável pela manutenção da paz e da ordem em seu reino. Essa ideia de

\footnotetext{
${ }^{9}$ No idioma original: El libro segundo trata de la organización judicial y el orden procesal, com sus materias distribuidas em cinco títulos: jueces, actos del proceso, procurados y abogados, testigos, valor de los acuerdos orales y escritos. (FJ, p. XXVIII).

${ }^{10}$ No original: Onde si alguno quiere obedezer á Dios, deve amar iusticia, e si la amar, deve fazerla todavia, y estonze ama omne la iusticia mas verdadera mientre, e mas firmementre, quando tiene um derecho com su próximo. Et por ende nos que queremos guardar los comendamientos de Dios, damos leyes em semble para nos, e para nuestros sometidos a que obedezcamos nos, e todos los reyes que vinieren depues de nos, e tod el pueblo que es de nuestro regno generalmientre. (FJ, II, I, II).
} 
Revista da Seção Judiciária do Rio de Janeiro

realeza era baseada na teoria do "vigário de Deus" ou corporativa, que tentava mostrar como a estrutura social estava organizada de acordo com os desígnios divinos.

No caso da Península Ibérica, a teoria do vicariato foi incluída ainda no século VII pelos visigodos em seu Liber Iudiciorum ou Iudicum:

O conceito de realeza elaborado pelos reis e seus conselheiros eclesiásticos desde Recáredo assentava na noção de ministerium Dei, de "vicariato" em nome de Deus. O Liber Iudicum de 654, no seu Livro II, título I, lei IV, já recorria à comparação com o corpo humano para explicar que o rei fora colocado por Deus à frente do corpo social. A primeira missão do rei era, pois, a salus populi, o bem-estar espiritual do povo, objeto igualmente das leis de que o soberano era, por vezes, a origem, e sempre o guardião. 0 exercício da justiça, a manutenção da paz e a colecta de impostos para garantir estes faziam, pois, parte das obrigações do rei, como a promulgação das leis e a defesa da fé. (RUCQUOI, 1995, p. 51).

O fato do rei também estar submetido às leis aumenta a força e a legitimidade das mesmas e demonstra o caráter virtuoso e o bom senso do monarca. Assim, ao criar leis e organizar o convívio social através do direito, o rei deve ter sempre como finalidade última o bem do povo, devendo ele mesmo agir nesse sentido.

A lei III prevê que ninguém poderia alegar desconhecimento da legislação como forma de se omitir de sua responsabilidade, devendo ser penalizado pelos crimes ou faltas mesmo assim. Esse ponto é interessante, pois a lei havia sido traduzida do latim para a língua local, o que de certa forma facilitava seu entendimento, mas não implicava em mudanças significativas quando se pensa no quantitativo de pessoas que, de fato, tinham acesso a ela naquele momento.

Na Lei IV o elemento corporativo é novamente utilizado ao justificar que "as coisas do príncipe devem ser ordenadas antes das coisas do povo" ${ }^{11}$, uma vez que ele é a "cabeça" do reino. O pensamento medieval era dominado pela teoria corporativa, ou seja, que a sociedade se organizava num nível coletivo e tinham um

\footnotetext{
${ }^{11}$ No idioma original: De las cosas del príncipe devem seer ante ordenadas, e las del pueblo depues. (FJ, II, I, IV).
} 
Revista da Seção Judiciária do Rio de Janeiro

objetivo comum a todos e onde todos, e cada um, tinham uma função muito bem determinada que garantiria a harmonia geral (HESPANHA, 1982, p. 205).

De acordo com essa ideia, que o Fuero Juzgo ratifica, as funções do rei eram claras e diziam respeito à organização e ao bom andamento do reino, a manutenção da justiça entre o povo, bem como a defesa deste. "Pois se a cabeça é sã, terá razão em si com a qual poderá sanar todos os outros membros; mas se a cabeça for enferma, não poderá manter os outros membros saudáveis, porque ela mesma não o é." (FJ, II, I, IV) ${ }^{12}$. Assim, esta lei reforça o papel desempenhado pelo monarca e sua importância para a sociedade.

As Leis V, VI e VII tratam especificamente de questões ligadas ao monarca. $\mathrm{Na} \mathrm{V}$ a abordagem reforça a ideia da responsabilidade dele para com o bem-estar social, inclusive limitando sua possível cobiça. A lei apresenta muitas disposições, mas seu tema central parece ser a separação entre o que são bens do reino e do rei, evitando que ele disponha daquilo que não é seu, mas de toda a comunidade. Já a Lei VI estabelece pena capital para traição ou tentativa de ataque ao monarca, e a Lei VII prevê diferentes penalidades para blasfêmia contra ele.

O interessante da Lei VII é que ela prevê penalidades diferenciadas a depender do autor do delito, se ele for de "grand guisa", posição social mais alta, ou vinculado a alguma ordem religiosa, apenas perde metade de seus bens que vão para o monarca. Já se for de outra classe perde não apenas os bens, como sua própria liberdade, já que o rei pode dispor de seu corpo como desejar.

As Leis VIII e IX enfatizam a validade do Fuero Juzgo como a legislação aplicável nos locais onde ele foi concedido, não devendo ser substituído por outros livros legais, mesmo que de origem romana. Isto é interessante se considerarmos que o próprio Fuero Juzgo é a tradução de um código jurídico fundamentado em

\footnotetext{
12 No idioma original: Ca si la cabeza es sana, avrá razon em si, porque podrá sanar todos los outros miembros; mas si la cabeza fuere enferma, non podrá dar salud a los outros mimebros, ca no la a em si. (FJ, II, I, IV).
} 
Revista da Seção Judiciária do Rio de Janeiro

grande parte nas leis romanas, mas que, apesar disso, reforça sua autoridade enquanto lei em vigor.

Há o entendimento de que o conhecimento de outras leis pode ser benéfico para o réu, podendo o mesmo utilizá-las caso estejam de acordo com o disposto no Fuero Juzgo. Por outro lado, tanto o réu quanto o juiz são penalizados financeiramente se tentarem fazer uso de outras leis ou fueros que estejam em discordância do Juzgo. A multa é paga então diretamente ao rei.

A partir da Lei X até a XXXI o conteúdo dos dispositivos está mais diretamente ligado às atribuições dos juízes nos pleitos, sua responsabilidade e ética ao julgar e seus direitos quando no exercício desta função. Destacamos algumas das leis que consideramos como sendo fundamentais para a compreensão do papel dos juízes conforme estabelecido no Fuero Juzgo.

A Lei XI coloca que os juízes só podem atuar em pleitos que estão de acordo com o previsto na lei e que casos alheios a isso devem ser levados ao rei. Aliado a isso, a Lei XII argumenta que os monarcas podem criar dispositivos legais conforme novas demandas e pleitos fossem surgindo, mas essas normas não seriam válidas para os casos já julgados anteriormente..$^{13}$

Algumas nuances do projeto de reforço da autoridade monárquica posto em prática no reinado afonsino, bem como a tentativa de organização da justiça podem ser vislumbradas nas leis XIII à XVI, onde são ditadas como os juízes deveriam ser escolhidos e sua esfera de atuação. A Lei XIII explicita já em seu título que o juiz deve ser escolhido pelo rei, pelas partes do processo em comum acordo ou mesmo pelos juízes já designados, caso eles não possam comparecer. Na Lei XVI se estabelecia a proibição de que um juiz atuasse em um pleito fora de sua jurisdição, ou seja, do local onde foi designado para julgar.

\footnotetext{
${ }^{13}$ Na Lei XII: "Y el prinicipe puede ennader leyes, segund cuemo los pleytos avinieren de nuevo, e devem valer asi cuemo las otras." (FJ, II, I, XII).
} 
Revista da Seção Judiciária do Rio de Janeiro

Essas são questões significativas, pois mostram maior envolvimento do rei no desenrolar do processo, seja criando novas leis, designando os juízes e determinando o local onde teriam ação, e mesmo estabelecendo seus direitos, como dias de trabalho ou férias. Apesar disso, a participação dos "homens bons" da aristocracia e dos senhores de vilas ou cidades na aplicação do direito continuava sendo importante, em um esforço conjunto pelo "bem comum" do reino.

Na Lei XVII se estabelece as formas pelas quais os juízes devem convocar os envolvidos nos pleitos para comparecer diante dele, normalmente por carta que deve ser entregue ao demandado diante de testemunhas, cabendo sanções físicas, como açoites, e financeiras caso este se recuse a atender o chamado. No caso de ambas as penalidades, a lei prevê variações de acordo com o status social do demandando e mesmo sua compleição física, já que o açoitamento não deveria causar enfermidade ou morte.

O Fuero Juzgo estipula também certa proteção para os indivíduos contra possíveis enganos ou abusos cometidos pelos juízes, como recusa em ouvir uma parte, demora excessiva na condução de um processo, tomar partido por uma parte específica, ou outras situações deste tipo. Nesses casos, se a parte prejudicada pudesse provar a má-fé do juiz, poderia receber deste multa correspondente ao ato praticado, conforme consta nas Leis XVIII à XX.

Em contrapartida, o juiz também poderia se resguardar pela lei de decisões tomadas por medo ou por ter sofrido coação de um príncipe, por exemplo, conforme dita a Lei XXVII. Isso está de acordo com a ideia do "bem comum", mas não deixa de ser intrigante pensar se isso de fato era colocado em prática e, em caso afirmativo, como se dava essa garantia, uma vez que não chegou aos dias atuais nenhum processo da época.

Para que pudesse bem julgar, o juiz deveria procurar sempre saber a verdade através dos testemunhos, das provas escritas e dos juramentos, e guardar escritos que comprovem suas decisões em pleitos, como forma de evitar disputas futuras. A 
Revista da Seção Judiciária do Rio de Janeiro

lei XXV dispõe que a todo aquele que for dado o poder de julgar que the seja conferido o cargo de juiz e que receba com ele os benefícios e as responsabilidades inerentes a essa atividade.

Naquele momento, como já discutido anteriormente, tanto o direito como as funções de justiça estavam se desenvolvendo de forma mais teórica e doutrinária, porém nos reinos, essa incumbência ainda era em grande parte assumida por membros da nobreza ligados ao rei, que não necessariamente tinham esse arcabouço intelectual, mas que conheciam o direito local.

A partir de então, principalmente com o uso do direito romano e canônico pelas monarquias, cada vez mais tornou-se necessário que os responsáveis pelas funções de justiça tivessem um conhecimento especializado e abrangente do direito, auxiliando o rei na criação de códigos próprios e na aplicação da lei.

Dessa forma, a sistematização das leis propiciava não somente maior organização da aplicação da justiça no interior do reino, como também a própria delimitação das responsabilidades que cabiam a cada um, seja ao rei, aos nobres, aos funcionários reais e aos membros da sociedade. As normativas presentes no Título "De los ivezes e de lo qve ivdgan" contribuíam para o reforço da autoridade monárquica, ao mesmo tempo que justificavam esse processo como sendo fundamental para a manutenção da ordem e da paz social.

\section{CONSIDERAÇÕES FINAIS}

O Fuero Juzgo foi um importante código jurídico promulgado no reinado de Fernando III (1217-1252) de Leão e Castela. A obra é uma versão castelhana do Liber Iudiciorum, antiga lei dos visigodos, que foi concedida aos territórios então incorporados ao reino castelhano-leonês por esse monarca. Tal empreitada inseriu-se em um processo de unificação que se estendia aos âmbitos social, jurídico, territorial, econômico e político. 
Revista da Seção Judiciária do Rio de Janeiro

Parte significativa do código está contida no Livro II, Título I "De los ivezes e de lo qve ivdgan", que tratam da importância das leis, bem como das atividades dos juízes, importantes atores no desenvolvimento e aplicação da justiça do reino. Nosso objetivo neste trabalho foi, portanto, apresentar o contexto histórico onde a obra foi retomada para, em seguida, analisar as normativas contidas neste Título e como elas se inserem nos propósitos da monarquia naquele momento.

Herdeiros de uma tradição jurídica já estabelecida, a Península Ibérica em geral e o reino de Leão e Castela em particular, apoiavam-se na origem romano-gótica para legitimar suas pretensões, o que não foi diferente com Fernando III. Após reunir as duas coroas em um processo permeado de conflitos internos e dar continuidade ao movimento expansionista sobre os territórios então sob domínio muçulmano, Fernando necessitava reorganizar o reino e garantir sua autoridade enquanto governante. Assim, tanto o direito quanto o próprio Fuero Juzgo foram instrumentos mobilizados com esse propósito.

As 31 leis que integram o Título I discorrem em geral sobre como os juízes deveriam atuar, mas reforçando a ideia de unificação jurídica ao limitar a pluralidade foral e incentivar o uso único do Fuero Juzgo. Além disso, elas legitimam a tradição e propõem a obediência de todos à lei, o rei inclusive, como garantia do bem comum.

A partir da análise das normas que tratam especificamente dos juízes, é possível perceber aspectos que vão muito além de apenas suas atribuições, mas se referem à organização da sociedade castelhana-leonesa daquele momento. Em seu próprio sentido, percebemos que se delimitam direitos e deveres de todas as partes envolvidas, o monarca, os juízes que em geral eram membros da nobreza, e os demais membros da comunidade.

As leis determinam o direito do juiz de ser apresentado como tal ou de convocar ao pleito através de seu selo e carta, mas limita um excesso de poder que poderia decorrer de um prolongamento desnecessário do processo ou recusa de ouvir uma das partes. Elas atribuem ao rei o direito de nomear juízes, mas também 
Revista da Seção Judiciária do Rio de Janeiro

às partes em acordo, e apresentam meios pelos quais um juiz poderia se livrar de uma pressão exercida pelo rei.

Apesar de não podermos ter certeza de que isso de fato ocorria na prática, sem dúvidas é um reflexo da renovação do direito que ocorria nos principais centros de poder e intelectualidade da Europa Ocidental. Os juízes ganhavam maior importância e responsabilidade nos vereditos e na aplicação da justiça como um todo, bem como procurava-se sistematizar o método pelo qual esse processo deveria ocorrer. Os indivíduos que levavam suas causas aos juízes tinham o direito de ser ouvidos e as leis também determinavam formas com as quais eles poderiam se prevenir de um julgamento injusto.

Assim, entendemos que o Fuero Juzgo e as leis do Livro II, Título I estão de acordo com a teoria corporativa medieval, que pressupõe que cada indivíduo tem um papel social determinado e que deve exercê-lo para que o equilíbrio e a paz sejam mantidas. Bem como com a renovação do direito e com os objetivos centralistas da monarquia castelhana do século XIII. 
Revista da Seção Judiciária do Rio de Janeiro

\section{REFERÊNCIAS}

\section{FONTES}

FUERO Juzgo. Edición de la Real Academia Española, 1815. Colección Leyes Históricas de España. Estudio preliminar de Santos. M. Coronas. Madrid: Imprenta Nacional de La Agencia Estatal Boletín Oficial del Estado, 2015.

\section{BIBLIOGRAFIA}

ANTÓN, J. M. M. Rey y reyno. Realeza, espacios políticos y poderes en las monarquías hispánicas (siglos XI-XII). In: ANTÓN, José Maria Monsalvo. (coord.). Historia de la España Medieval. Salamanca: Ediciones Universidad de Salamanca, 2014.

BEJDER, M. S. O rei e a lei: definições do poder real na análise do Fuero Juzgo. In: XIII Encontro de História da ANPUH, 13, 2008, Seropédica. Anais eletrônicos [...]. Seropédica: ANPUH, 2008. Disponível em:

http://encontro2008.rj.anpuh.org/resources/content/anais/1212931726_ARQUIVO_a npuhregional2008.pdf. Acesso em: 05 set. 2021.

FITZ, F. G. Edad Media: guerra e ideologia, justificaciones jurídicas y religiosas. Madrid: Sílex, 2003.

GARCÍA-GALLO DE DIEGO, A. La obra legislativa de Alfonso X. Hechos y hipótesis. Anuario de historia del derecho español, [s. I.], n. 54, p. 97 - 162, 1984. Disponível em:

https://www.boe.es/publicaciones/anuarios_derecho/articulo.php?id=ANU-H-1984-10 009700162. Acesso em: 5 set. 2021.

GILISSEN, J. Introdução histórica ao Direito. Tradução A. M. Hespanha. Lisboa: Fundação Calouste Gulbenkian, 1995.

HESPANHA. A. M. História das Instituições: Épocas medieval e moderna. Coimbra: Livraria Almedina, 1982.

LEME, L. M. O direito na Península Ibérica. Revista da Faculdade de Direito da USP, [s. l.], v. 53, p. 74 - 88, 1958. Disponível em:

http://www.revistas.usp.br/rfdusp/article/view/66283. Acesso em: 20 jul. 2019.

\section{REIS, J. E. Território, legislação e monarquia no reinado de Alfonso $\mathbf{X}, \mathbf{0}$}

Sábio (1252-1284). 2007. Tese (doutorado em História) - Faculdade de Ciências e 
Revista da Seção Judiciária do Rio de Janeiro

Letras de Assis, Universidade Estadual Paulista, São Paulo, 2007. Disponível em: http://hdl.handle.net/11449/103168. Acesso em: 05 set. 2021.

RUCQUOI, Adeline. História Medieval da Península Ibérica. Lisboa: Editorial Estampa, 1995.

SCHIOPPA. A. P. História do Direito na Europa: Da Idade Média à Idade Contemporânea. São Paulo: Editora WMF Martins Fontes, 2014.

SILVEIRA. M. C. As penalidades corporais: uma análise comparativa do Fuero Real e do Fuero Juzgo. In: XVII Encontro de História da Anpuh-Rio - Entre o local e o global, 17, 2016, Nova Iguaçu. Anais [...]. Nova Iguaçu: ANPUH, 2016. Disponível em:

http://www.encontro2016.rj.anpuh.org/resources/anais/42/1471214192_ARQUIVO_ MartadeCarvalhoSilveira.pdf. Acesso em: 03 dez. 2021.

VEREZA, R. A monarquia centralizadora e a articulação jurídico-política do reino: Castela no século XIII. Revista Internacional de História Política e Cultura Jurídica, Rio de Janeiro, v. 5, n. 1, p. 52-66, 2013. Disponível em: https://www.redalyc.org/articulo.oa?id=337327390004. Acesso em: 05 set. 2021. 